\title{
Water consumption of the wine grape varieties Kövidinka K.8 and White Riesling B.7
}

Hajdu E., Miklós E. and Gábor Gy.

Research Institute for Viticulture and Enology of Ministry of

Agriculture

and Rural Development

H-6001 Kecskemét P.O.B. 25, Hungary

Key words: leaf area, hairness, stoma, water consumption, wine grape variety, model trial

Summary: In the Carpathian Basin Kövidinka and White Riesling are promising wine grape varieties. As in the region continental climate dominates and dry years are not uncommon it was natural to study the water requirement and consumption of the two varieties.

Morphological characters affecting transpiration were observed including leaf area, hairiness, number and type of stomata. The amount of water transpired per unit leaf area and time and rate of water consumption were measured in a model trial in cuttings with known water supply.

The water consumption of vine cuttings depends on varieties and is determined by the genotype but it is also affected by environment. Kövidinka requires little water and uses it to its advantage White Riesling requires more water and uses it rather lavishly. The results of our model trial could be introduced directly into viticulture practice.

\section{Introduction}

The vine stock uses 250-300 g water to build up $1 \mathrm{~g}$ solids (Kozma, 1967). The vine has a moderate water requirement and can tolerate drought conditions for a long time (Füri et al., 1977). However, water deficiency, especially during the growing period, can reduce assimilation, yield and even vitality. In severe cases of drought the whole stock can die.

Water deficiency is quite common in arid regions under continental climate where precipitation is low $(300-500$ $\mathrm{mm} /$ year) or unfavourably distributed with soils of unsatisfactory water regimes (e.g. sand, rendzina). In some cases severe damage can occur which is only enhanced by wind, low air humidity, vigorous growth of shallow roots (Hajdu, 1984) and/or overloading. In the survival of stocks the anatomical structure of the varieties (leaf area number of stoma, hairness) - which are genetically determined - play an important part (Geisler, 1960; Scienza, 1981). In grafts the rootstock influences the water regime of scions (Geisler, 1957; Kozma, 1967). Several scientists studied the water requirement of wine grape varieties (Kozma, 1967; Bravdo et al., 1972; Reuter, 1975; Füri-Kozma, 1977; Füri et al., 1988).

A model trial was used to study the water consumption and the effect anatomical characters of the vine on two promising wine grape varieties, Kövidinka and White Riesling, in the lowland vine regions of the Carpathian
Basin. The trial was sponsored by an OTKA (Hungarian Scientific Research Fund) project No. T 023893.

\section{Material and methods}

The trial was set up in the glasshouse of the Research Institute for Viticulture and Enology at Kecskemét for 2 years (1997-1998). Two varieties were chosen which differed in drought tolerance but were very popular in the lowlands of arid character.

Most important agronomic characteristics are the following (Csepregi-Zilai, 1988, Hajdu, 1992, 1999):

Kövidinka:

- late bud burst but long growing period,

- buds are frost sensitive but stocks can regenerate after frosts,

- high yielding, no or hardly any berry rot,

- airy foliage, hardly any lateral shoots,

- drought tolerance,

- long and deep roots,

- reliable yield,

- resistance to diseases,

- wine: pleasant table wine of reliable quality,

Tested clone: Kövidinka K.8 


\section{White Riesling:}

- mid-long growing period (budding and ripening medium-early),

- buds tolerate frosts up to $-23^{\circ} \mathrm{C}$,

- moderate yield, sensitive to berr rot,

- high demand of summer pruning, dense, short lateral shoots,

- less tolerant to drought,

- shallow roots,

- susceptible to diseases, especially to powdery mildew and Botrytis,

- wine: quality wine of fine bouquet and aroma,

Tested clone: White Riesling B.7.

Trials were carried on after Füri et al. (1988) (Fig.l). Ungrafted material could be used, because Phylloxera does not live in light, sandy soil, where we can make good use of the results.

Two-bud canes of the varieties was rooted in perlite. Rooting material were planted in glass jars of $700 \mathrm{~cm}^{3}$ containing perlite $\mathrm{P}_{1}$. Perlite was filled with tap water to $70 \%$ of its water capacity. When the new roots appeared at the wall of the jar the container was sealed with paraffin to prevent evaporation. So, the plants didn't receive more water during the experiment. Every cutting was pinched back to

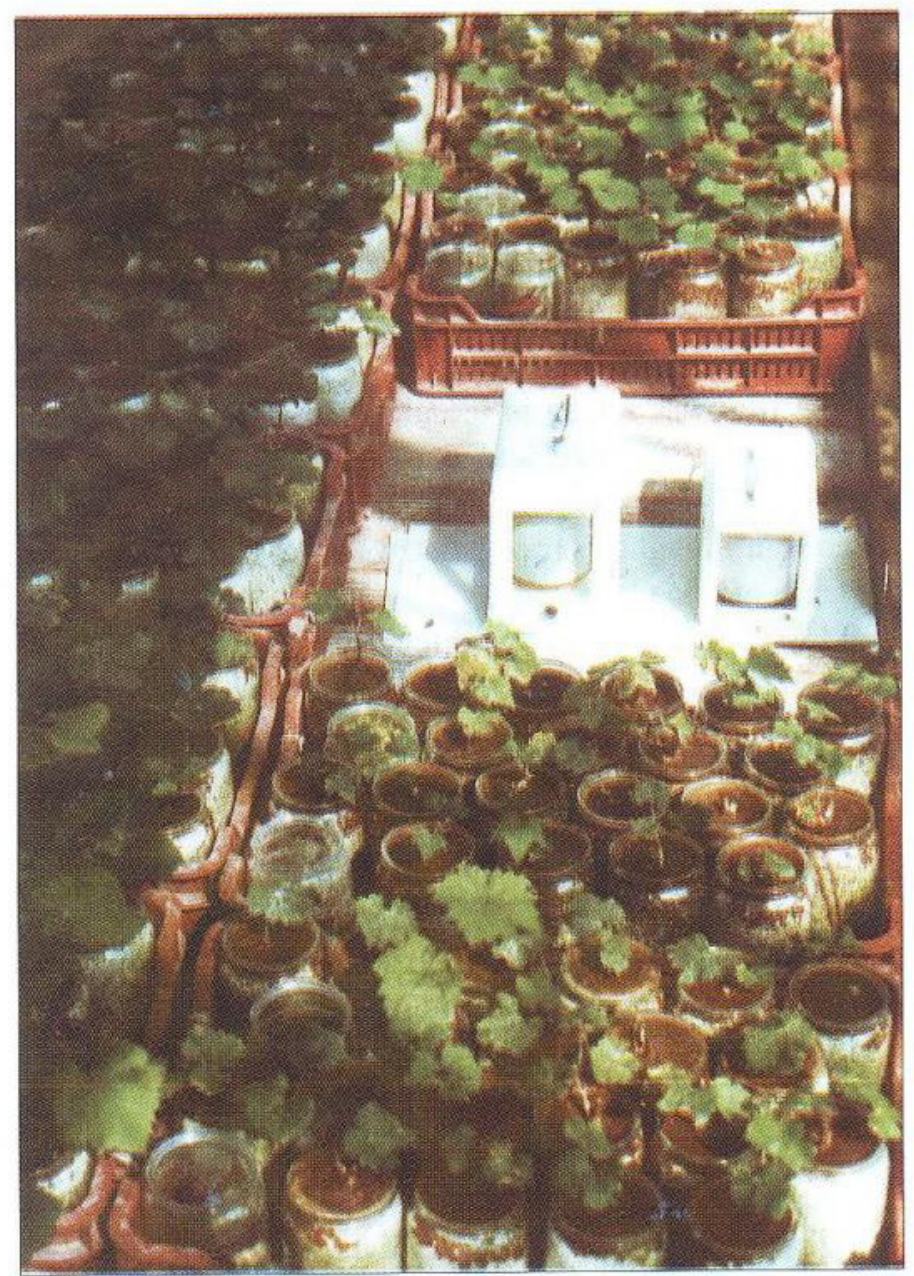

Figure 1 Model trial of water consumption

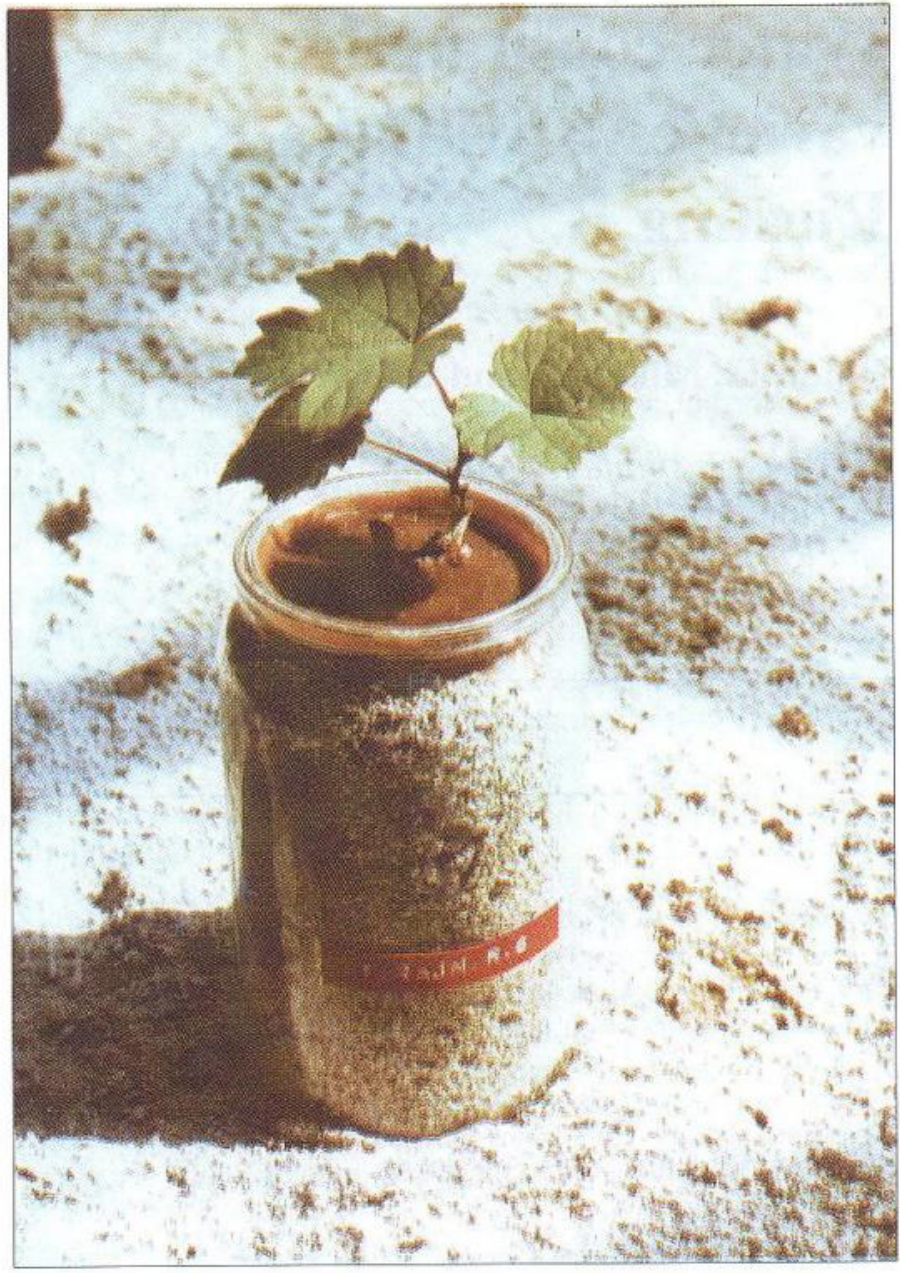

Figure 2 The rooted cutting with 3 leaves in glass jar

3-4 leaves (Fig.2). Leaf area was measured by a planimeter (Planix) immediately at the beginning of the trials. Containers (30/variety) were weighed twice a week to follow the water consumption rate of the plants. Knowing the water consumption and leaf area, the rate and dynamics of water consumption could be calculated for each plant.

Duration of measurements:

In 199784 days (22 June - 15 Sept.)

In 199864 days (14 Aug. - 16 Oct.)

This period lasted from the sealing of the containers (perlite) to the fall of leaves. The weight of cuttings was measured prior to planting and after leaf fall.

Beside the water consumption measurements, the hairiness; number, size and type of stomata were also studied on young and well developed leaves of both varieties under electron microscope. Young leaves were collected from cuttings and the well developed ones from the 8 th-12 th nodes of the cane in field (400-420 leaves/variety). Number of stoma was counted in 430 enlargement in a $18 \times 24 \mu \mathrm{m}$ field and size of stoma (length and width) was determined in 2000 enlargement. Microscopic tests and photos were performed by colleagues of the Central Laboratory of the University for Horticulture and Food Industry in Budapest. 


\section{Results}

\section{Evolution of cuttings in the containers}

In our model trial, container weight was nearly identical in both years. Table $I$ shows the weight of container parts (glass jar, cuttings, perlite, water, wax) at the beginning and at the end of the trial. The weight of cuttings decreased by the end of the trial due to the fall of leaves and the ripening of green buds which means loss of water. The weight of wax decreased in such a low amount $(0.09-0.13 \%)$ that is could be omitted. The water content in the jars decreased from $51.4 \%$ to $15.0 \%$ by the end of the trial in the mean of varieties and years. It was interesting to observe the change in weight of cuttings (Table 2).

Table I Distribution of container weight in the mean of two varieties (Kecskemét, 1997-1998)

\begin{tabular}{|c|c|c|c|c|}
\hline \multirow{3}{*}{ Container and parts } & \multicolumn{4}{|c|}{ Weight } \\
\hline & \multicolumn{2}{|c|}{1997} & \multicolumn{2}{|c|}{1998} \\
\hline & $\mathrm{g}$ & $\%$ & $\mathrm{~g}$ & $\%$ \\
\hline Initial total weight & 1032 & 100.0 & 1034 & 100,0 \\
\hline glass jar & 348 & 33.7 & 347 & 33,6 \\
\hline plant with shoot & 11 & 1.1 & 23 & 2.2 \\
\hline perlite & 101 & 9.8 & 92 & 8.9 \\
\hline water & 523 & 50,7 & 539 & 52.1 \\
\hline wax & 49 & 4.7 & 33 & 3.2 \\
\hline Final total weight & 662 & 64.1 & 642 & 62.1 \\
\hline glass jar & 348 & 33.7 & 347 & 33.6 \\
\hline plant & 9 & 0.9 & 14 & 1.4 \\
\hline perlite & 101 & 9.8 & 92 & 8.9 \\
\hline water & 155 & 15.0 & 156 & 15.0 \\
\hline wax & 49 & 4.7 & 33 & 3,2 \\
\hline Control & & & & \\
\hline initial weight & 897.4 & 100.0 & 932.1 & 100.0 \\
\hline final weight & 896.6 & -0.09 & 930.9 & -0.13 \\
\hline
\end{tabular}

The weight of cuttings differed by $50 \%$ during the growing period at the beginning of the trial in the two years. In 1997 rooting material was only 3 months old while in 1998 rooted and vigorous cuttings of 2 years were used.
Table 2 Cutting weight of Kövidinka K.8 and White riesling B.7 (Kecskemét, 1997-1998)

\begin{tabular}{|l|r|r|r|r|}
\hline \multirow{2}{*}{ Cutting and parts } & \multicolumn{4}{|c|}{ Weight (g) } \\
\cline { 2 - 5 } & \multicolumn{2}{|c|}{1997} & \multicolumn{2}{|c|}{1998} \\
\cline { 2 - 5 } & \multicolumn{1}{|c|}{$\mathrm{x}$} & $\mathrm{s}$ & $\mathrm{x}$ & $\mathrm{s}$ \\
\hline \multirow{2}{*}{ Plant weight } & \multicolumn{3}{|c|}{ KÖVIDINKA } & K.8 \\
during growing & 11.2 & 3.0892 & 23.4 & 4.92344 \\
in dormancy & 9.7 & 2.4954 & 25.6 & 2.93254 \\
deviation in \% & -13.4 & & +9.4 & \\
OF THS: & & & & \\
root & 1.6 & 0.5617 & 7.0 & 2.22082 \\
cane & 8.1 & 2.7238 & 18.6 & 5.06888 \\
& & & \\
Plant weight & WHITE RIESLING B.7 & \\
during growing & 11.4 & 2.786 & 21.0 & 4.8057 \\
in dormancy & 7.8 & 1.828 & 22.0 & 2.7354 \\
deviation in \% & -31.6 & & +4.8 & \\
OF THIS: & & & & \\
root & 1.2 & 0.321 & 6.1 & 1.8337 \\
cane & 6.6 & 1.828 & 15.9 & 4,8747 \\
\hline
\end{tabular}

Frequency: $\mathrm{n}=30$ cuttings/year/variety

At the end of the growing period the weight of cuttings decreased in both varieties in 1997 while in 1998 an increase of $4.8-9.4 \%$ was observed.

The roots and canes of cuttings - due to their different development - doubled by the end of the growing period in 1998 related to 1997.

In both years (1997-1998) Kövidinka K.8 had heavier roots and canes than White Riesling B.7.

\section{Morphological characteristics}

Drought tolerance can be expressed by some morphological characters such as leaf area, hairiness, number, size and structure of stomata on the back of the leaf. (Table 3.)

\subsection{Leaf area}

The area of the leaf varied according to varieties. In Kövidinka K.8 the mean area of well developed (aged) leaves

Table 3 Leaf are hairiness and stomata in the varieties Kövidinka K.8 and White riesling B.7

(Kecskemét, 1999)

\begin{tabular}{|c|c|c|c|c|c|c|c|c|c|c|}
\hline \multicolumn{3}{|c|}{ LEAF } & \multicolumn{8}{|c|}{$\mathrm{S}$ TOM A } \\
\hline \multirow{3}{*}{ AGE } & \multirow{3}{*}{ HAIRINESS } & \multirow{3}{*}{ AREA $\mathrm{cm}^{2}$} & \multicolumn{6}{|c|}{$\operatorname{NUMBER}\left(\mathrm{db} / \mathrm{mm}^{2}\right)$} & \multicolumn{2}{|c|}{ SIZE $(\mu \mathrm{m})$} \\
\hline & & & \multicolumn{5}{|c|}{ TYPE } & TOTAL & OUTSIDE & INSIDE \\
\hline & & & 1 & 2 & 3 & 4 & 5 & & length $\mathrm{x}$ width & length $\mathrm{x}$ width \\
\hline & & & \multicolumn{6}{|c|}{ KÖVIDINKA K.8 } & 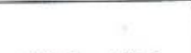 & \\
\hline YOUNG & VERY WOOLLY & 37,6 & 26 & 43 & 8 & 6 & 3 & 86 & $28,0 \times 16,5$ & $23,1 \times 7,8$ \\
\hline AGED & VERY WOOLLY & 172,0 & 22 & 17 & 13 & 16 & 4 & 72 & $32,1 \times 17,5$ & $27,2 \times 9,7$ \\
\hline & & & \multicolumn{6}{|c|}{ WHITE RIESLING B.7 } & & \\
\hline YOUNG & COBWEBBY & 31,3 & 19 & 30 & 20 & 4 & 1 & 74 & $32,5 \times 19,5$ & $27,0 \times 10,4$ \\
\hline AGED & COBWEBBY & 191,1 & 9 & 16 & 10 & 35 & 9 & 79 & $32,1 \times 23,1$ & $25,6 \times 11,4$ \\
\hline
\end{tabular}

STOMA TYPE: $\quad 1$ = below epidermis level $\quad 4=$ cmerging from epidermis 


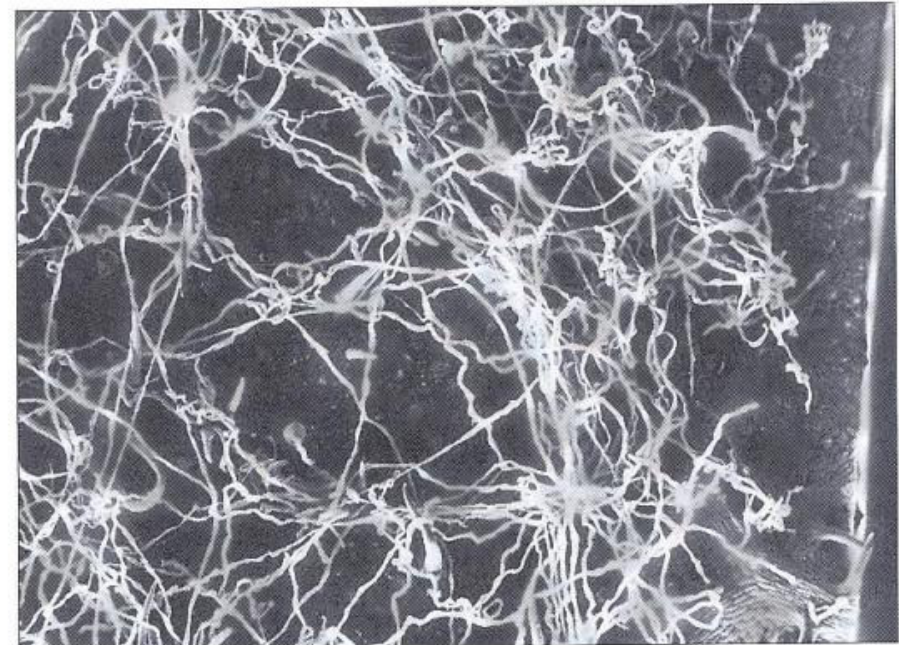

Figure 3 Very woolly leaf back in Kövidinka K. 8 (100 x magnification )

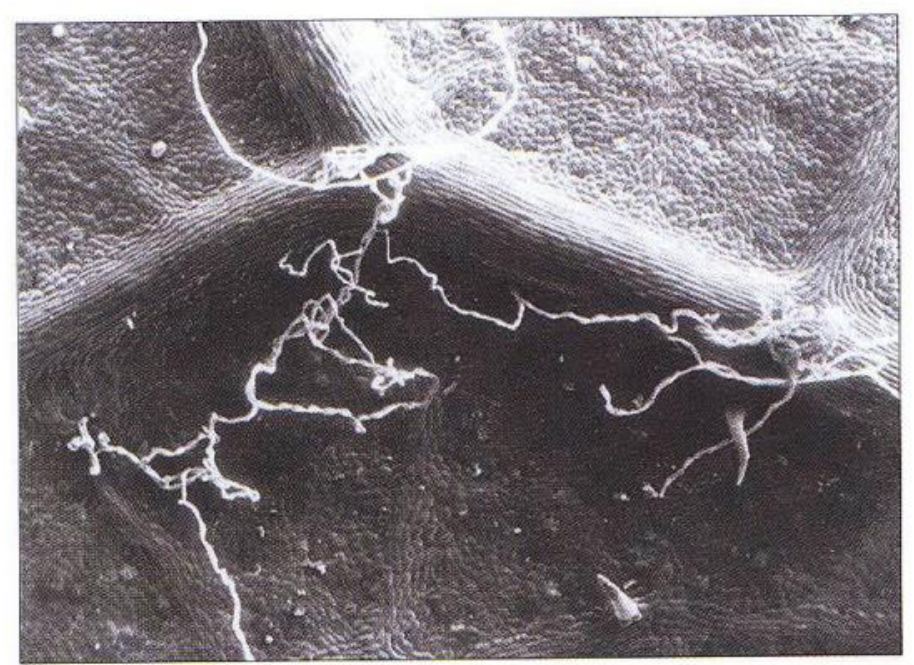

Figure 4 Cobwebby leaf back in White Riesling B.7 (100 x magnification)

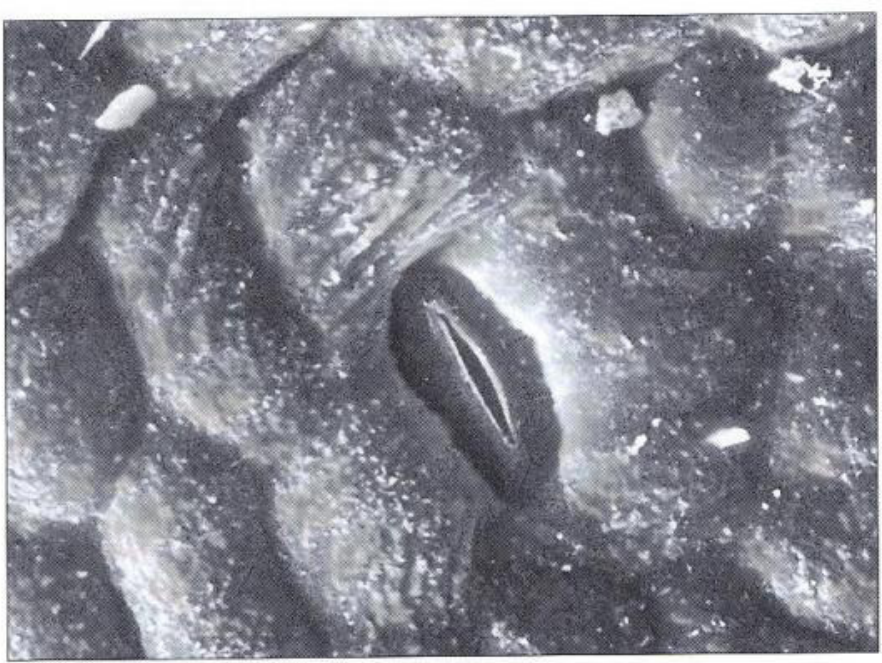

Figure 5 Stoma sunk into epidermis ( $250 \mathrm{x}$ magnification)
- which is characteristic for the variety - was $11.1 \%$ smaller than in White Riesling B.7. In young leaves of the cuttings just the contrary was found. The mean leaf area of White Riesling B. 7 was by $21.1 \%$ smaller than at Kövidinka K.8. The reason is that on cuttings of Kövidinka K.8 the leaves developed earlier than on White Riesling B.7. On the basis of our results we suppose that White Riesling $B .7$ has a relatively larger transpiration area than the other variety.

\subsection{Leaf hairness}

Different hair-types (e.g. bristles, coarse hair) exist on leaves. The hairs forma tomentose, cobwebby and velvety surface on the leaves (Kárpáti et al., 1968). In general, very hairy leaves tolerate water deficiency fairly well. Similar observation was made in wine grape varieties. Leaves of the varieties belonging to the group Vitis vinifera $L$. convar. pontica are woolly which means that they tolerate drought, as found in Ezerjó, Kadarka and Kövidinka. As observations indicate the type of hairness does not depend on leaf age and is determined by the genotype. The young and the aged leaves of Kövidinka K.8 are very woolly (Fig. 3). On leaves of White Riesling B.7 sparse short and long hair are found (Fig. 4).Obviously, the microclimate on woolly leaves favours the slow transpiration rate of the stomata.

\subsection{Stomata}

Differences were observed in number, type and size of stomata of the varieties tested (Table 3). The deusty of stomata was 166 to 198 ver $1 \mathrm{~mm}^{2}$. Düring (1980) found similar number of stomata $\left(142.4-209.9 / \mathrm{mm}^{2}\right)$ on leaves of White Riesling, Kárpáti et al. (1968) groups stomata in three types:

1. stomata on level of epidermis

2. stomata under the level of epidermis

3. stomata, which emerge from epidermis

According to them, the environment and the climate determine the position of stomata.

In young leaves of Kövidinka K.8 stomata were more numerous and their size were smaller than in White Riesling B.7. In the same time, in both varieties stoma types 2 (sunk into the epidermis) (Fig. 5) and 1 (on a level with epidermis) dominated, that these types come up to $66-80 \%$ of all the stomata.

On aged leaves stomata were fewer and their size were smaller in Kövidinka K.8 than in White Riesling B.7. Types stoma varied greatly. The normal stoma structure (Fig. 6) was not characteristic for either variety. $54 \%$ of the stoma of Kövidinka K.8 were found on the same level with the epidermis or below it. There were only few which emerged above it (Fig. 7). In White Riesling B.7 56\% of the stomata emerged from the epidermis.

\section{Rate and schedule of water consumption}

Measurements included the leaf area of the cuttings (transpiration area) and the water content of the containers. 


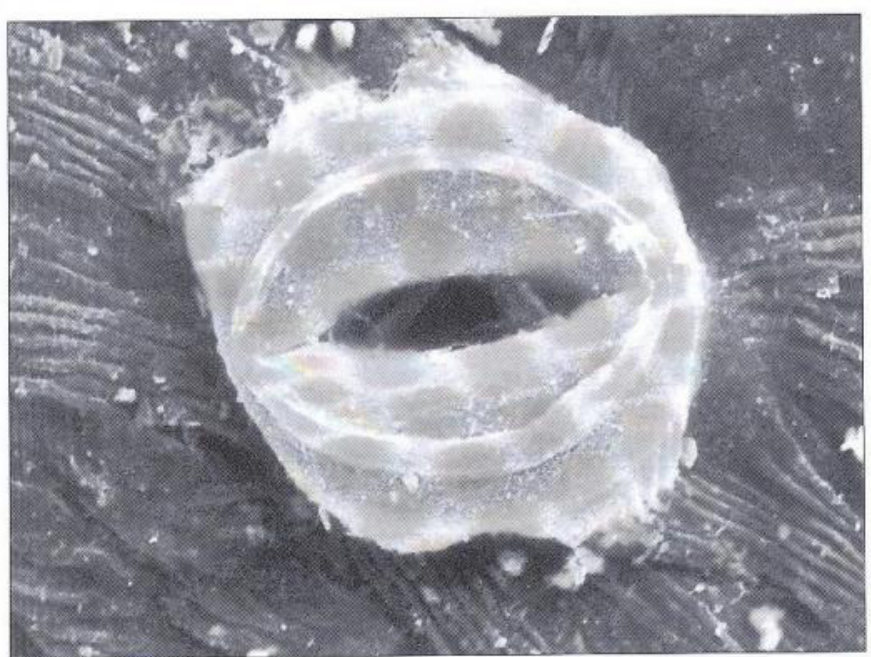

Figure 7 Stoma emerging from epidermis (2500 x magnification)

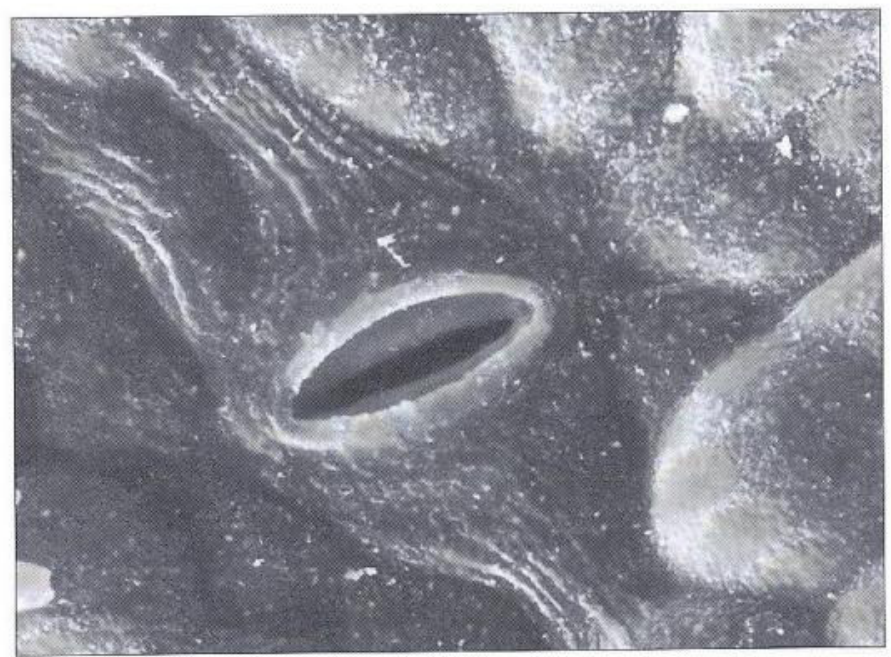

Figure 6 Normal stoma (2500 x magnification)

Table 4 Water consumption rate in the varieties Kövidinka K.8 and White Riesling B.7

(Kecskemét, 1997-1998)

\begin{tabular}{|c|c|c|c|c|c|c|c|c|}
\hline \multirow{3}{*}{ Year } & \multirow{3}{*}{$\begin{array}{c}\text { Number days in } \\
\text { the growing } \\
\text { period }\end{array}$} & \multicolumn{3}{|c|}{ Leaf area } & \multicolumn{4}{|c|}{ Water consumption rate } \\
\hline & & \multicolumn{2}{|c|}{$\mathrm{cm}^{2} /$ leaf } & $\mathrm{cm}^{2} /$ cutting & \multicolumn{2}{|c|}{$\mathrm{g} / \mathrm{cm}^{2}$} & \multicolumn{2}{|c|}{$\mathrm{g} / \mathrm{cm}^{2} /$ day } \\
\hline & & $\mathrm{x}$ & s & $\mathrm{x}$ & $x$ & $\mathrm{~s}$ & $x$ & $\mathrm{~s}$ \\
\hline & & \multicolumn{7}{|c|}{ KÖVIDINKA K.8 } \\
\hline 1997 & 84 & 37,0 & 10,24 & 111,0 & 9,335 & 3,217 & 0,111 & 0,038 \\
\hline 1998 & 64 & 38,2 & 8,29 & 152,8 & 7,196 & 2,347 & 0,112 & 0,037 \\
\hline Mean: & & 37,6 & & 131,9 & 8,266 & & 0,112 & \\
\hline & & \multicolumn{7}{|c|}{ WHITE RIESLING $\quad$ B.7 } \\
\hline 1997 & 84 & 31,0 & 4,71 & 93,0 & 11,296 & 2,159 & 0,135 & 0,026 \\
\hline 1998 & 64 & 31,5 & 7,28 & 126,0 & 7,291 & 2,107 & 0,114 & 0,033 \\
\hline Mean: & & 31,3 & & 109,5 & 9,293 & & 0,124 & \\
\hline
\end{tabular}

Cuttings absorbed that water during the growing period. Both varieties transpired more water during the 84 days in 1997 than in 1998 during 60 days (Table 4).

The rate of water consumption (per day) unit leaf area is specific for the variety (Table 4). During the same time White Riesling $B .7$ transpired more water per unit leaf area and time than Kövidinka K.8. did Füri et al. (1988) observed similar results. The decrease in the water content in the containers agreed with the rate of water consumption. The intensity of daily consumption depends on the varieties (Fig. 8). White Riesling B.7 responded quicker to outside conditions (temperature, air, humidity) than Kövidinka K.8. did. This quick reaction resulted in more water uptake and transpiration in both years (1997-1998).

\section{Conclusions}

The model trial was adequate to test water consumption. Wine grape varieties differ in the rate and schedule of water consumption under similar environmental conditions. Kövidinka K.8 has low water requirement and uses water more economically as indicated by the morphological traits (very woolly leaf, few and small stomata that mostly sink into the epidermis) resulting in its well-known drought tolerance.

White Riesling B.7 uses more water and rather scarcely. Its leaves are scantily haired, stomata are more numerous and larger, in the majority emerging from the epidermis. Conditions for higher rate of transpiration are given. Trials indicate that Kövidinka K.8 would tolerate drought better in arid regions than White Riesling B.7. Accordingly, for White Riesling B.7 drought tolerant rootstocks ought to be chosen.

\section{Acknowledgement}

Thanks to Mrs. A. Ésik and É. Borbás for their conscientious work in setting up and evaluating the trial and to Barbara Nagy for the electronmicroscope photos and evaluation. 


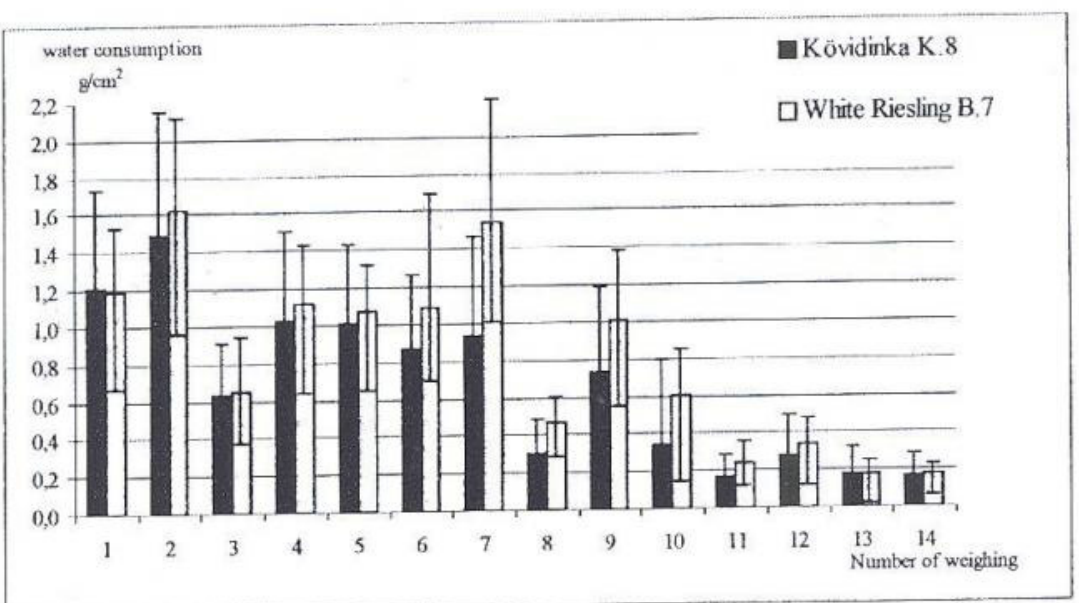

Growing period: $22,06,1997,-15,09,1997 .(84$ nap)

1998

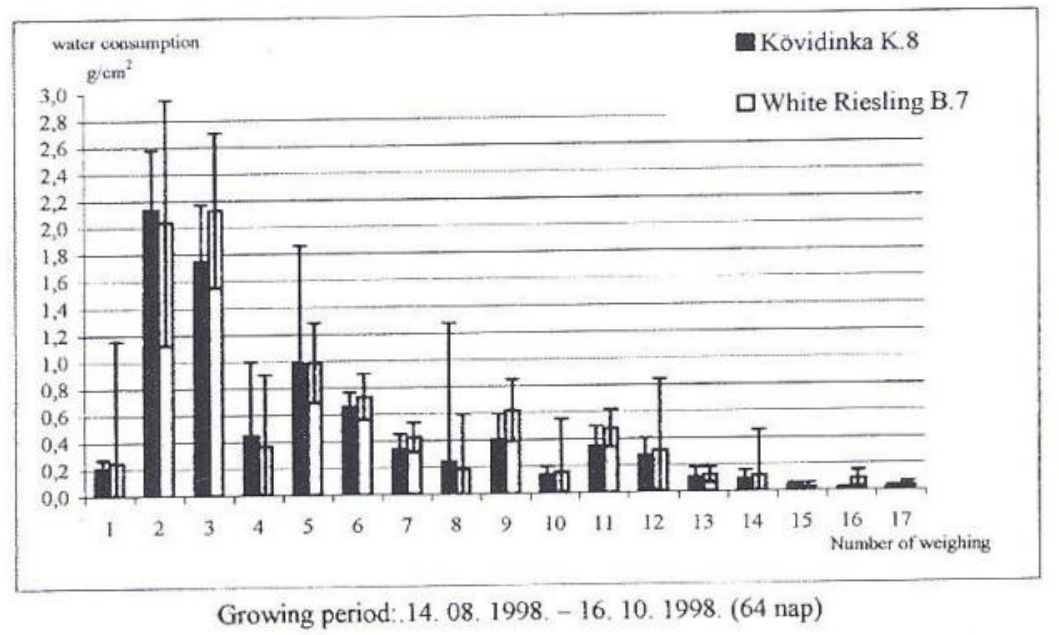

Figure 8 Water consumption rhythm in the varieties Kövidinka K.8 and Whiter Riesling B.7 (Kecskemét, 1997-1998)

\section{References}

Bravdo, B., Lavee, S. \& Samish, R. M. (1972): Analysis of water consumption of various grapevine cultivars. Vitis 10, 279-291.

Csepregi P. \& Zilai J. (1988): Szólófajta - ismeret és használat. Mezốgazdasági Kiadó. Budapest. (508) 137-148.

Düring, H. (1980): Stomafrequenz bei Blättern von Vitis-Arten und -Sorten. Vitis 19, 91-98.

Füri J. \& Kozma F. (1977): Der Wasserverbrauch und bedarf der Reben während der Vegetationsperiode. Wein-Wissenschaft. 32, 103-121.

Füri J., Hajdu E. \& Kishonti A. (1988): Néhány szốlốfajta vízfogyasztásának mértéke. Szôloôtermesztés és Borászat. Kecskemét. $10(2-3)$ 21-23.

Geisler G. (1957): Die Bedeutung des Wurzelsystems für die Züchtung dürreresistenter Rebenunterlagsorten. Vitis 1, 14-31.

Geisler G. (1960): Die Bedeutung blattmorphologischer Merkmale für die Züchtung dürreresistenter Rebenunterlagsorten. Vitis 2, 153-171.

Hajdu E. (1984): A szőló életét veszélyeztetổ harmatgyökerek. Kertészet és Szólészet. Budapest. 33(38)13.
Hajdu E. (1992): Téli fagyok és nyári aszályok után a Rajnai rizling Gm.239 termesztési értéke oltványon és saját gyökéren az Alföldön. Kertgazdaság. Budapest. 24(3)77-87.

Hajdu E. (1999): Die Bedeutung der Dürretoleranz der Rebsorten in trockenen Jahren. Das Deutsches Weinbau - Jahrbuch 1999. Waldkirch. 50(376) 93-98.

Kárpáti Z., Görgényi L-né \& Terpó A. (1968): Növényszervezettan. Mezốgazdasági Kiadó. Budapest. (381) 88-93.

Kozma P. (1967): Szôlőtermesztés I. Mezógazdasági Kiadó. Budapest. (347) 133-239.

Moog, H. (1957): Einführung in dic Rebsortenkunde. Stuttgart. E. Ulmer in: Currle, O.-Bauer, O.-Hofäcker, W.-Schumann, F.-Frisch, W. (1983): Biologie der Rebe D. Meininger Verlag und Druckerei GmbH. Neustadt an der Weinstrasse. (311) 47.

Reuter G. (1975): Physiologische Kriterien der Klimaresistenz als sortenspezifische Merkmale. Angew. Bot. 49, 75-91.

Scienza, A. \& Boselli, M. (1981): Fréquence et caractéristique biometriques des stomates de certains porte-greffes de vigne. Vitis 20, 281-292. 